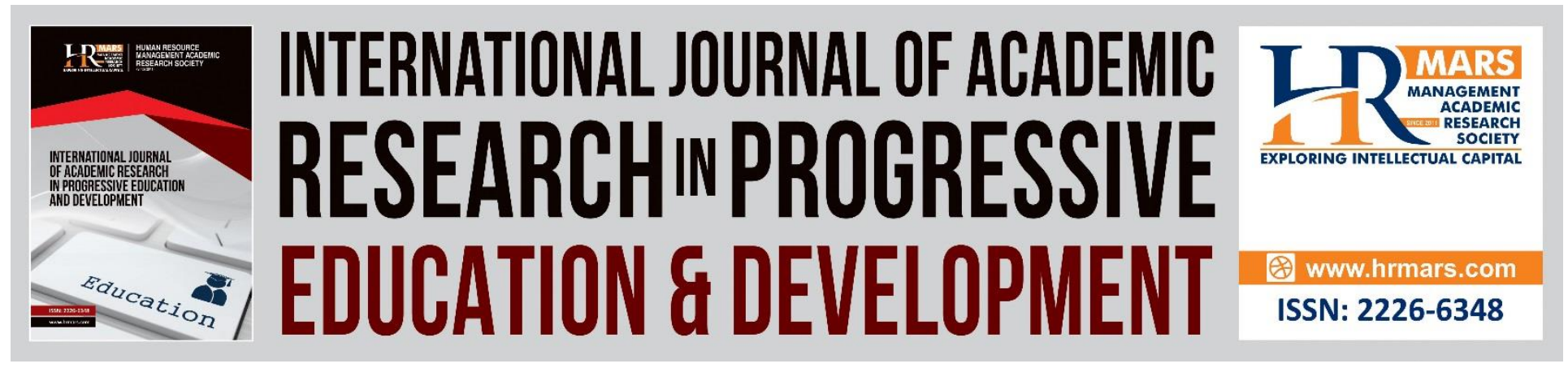

\title{
Developing Thinking Skills in Teaching English as a Second/Foreign Language at Primary School
}

Hesam Tahsildar Tehrani \& Abu Bakar Razali

To Link this Article: http://dx.doi.org/10.6007/IJARPED/v7-i4/4755

DOI: $10.6007 /$ IJARPED/v7-i4/4755

Received: 17 Sept 2018, Revised: 28 October 2018, Accepted: 03 Nov 2018

Published Online: 10 Nov 2018

In-Text Citation: (Tehrani \& Razali, 2018)

To Cite this Article: Tehrani, H. T., \& Razali, A. B. (2018). Developing Thinking Skills in Teaching English as a Second/Foreign Language at Primary School. International Journal of Academic Research in Progressive Education and Development, 7(4), 13-29.

Copyright: (c) 2018 The Author(s)

Published by Human Resource Management Academic Research Society (www.hrmars.com)

This article is published under the Creative Commons Attribution (CC BY 4.0) license. Anyone may reproduce, distribute, translate and create derivative works of this article (for both commercial and non-commercial purposes), subject to full attribution to the original publication and authors. The full terms of this license may be seen

at: http://creativecommons.org/licences/by/4.0/legalcode

Vol. 7, No. 4, 2018, Pg. 13 - 29

http://hrmars.com/index.php/pages/detail/IJARPED

JOURNAL HOMEPAGE

Full Terms \& Conditions of access and use can be found at http://hrmars.com/index.php/pages/detail/publication-ethics 


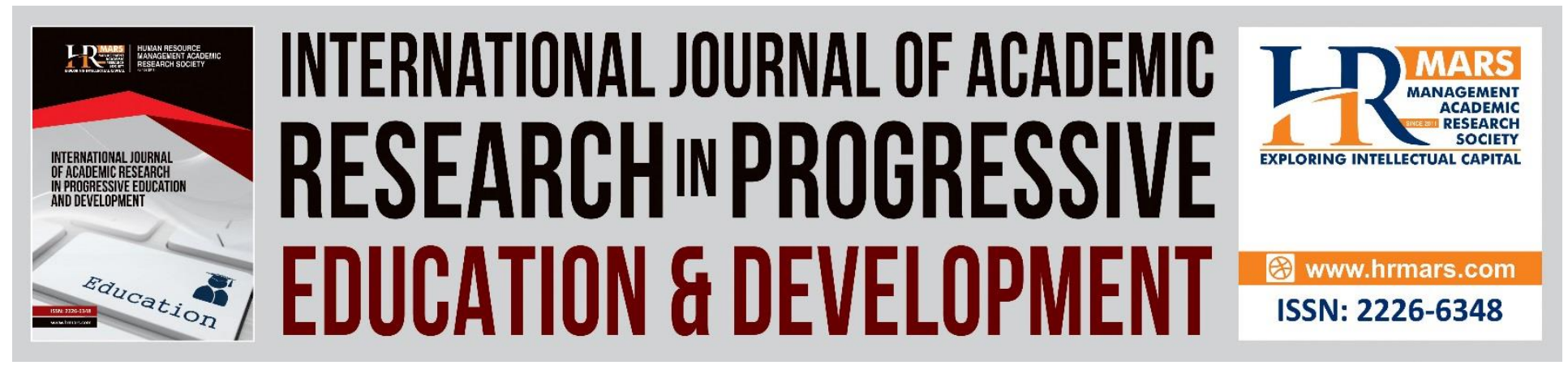

\title{
Developing Thinking Skills in Teaching English as a Second/Foreign Language at Primary School
}

\author{
Hesam Tahsildar Tehrani \& Abu Bakar Razali \\ Faculty of Educational Studies, University Putra Malaysia, 43400 UPM Serdang, Selangor Darul \\ Ehsan, Malaysia
}

\begin{abstract}
Developing skillful thinking contribute to young language learners' language skills (Goh \& Taib, 2006) and is a fundamental goal in educating school children in general (Hu et al., 2011) and in teaching English to young learners in particular (G. Ellis \& Brewster, 2014). Fostering thinking skills develops school children's cognitive abilities and leads to positive curricular outcomes (Higgins, Hall, Baumfield, \& Moseley, 2005). However, despite the role of thinking skills in second language learning and teachers' interest in thinking skills at the level of primary school (Alwadai, 2014; Gashan, 2015), the practice of teaching thinking skills at primary school is still lacking (Anyachebelu, 2012; Polat, 2015; Rodrigues, 2006). There is only modest contribution of the teachers' practices to teaching thinking skills (Sardare \& Saad, 2013) and there is a dire need for further work on primary students' synthesis, analysis, and interpretation skills (Pilten, 2010). In addition, teachers of English language require practical ideas to improve students' thinking skills (Adams, 2013) especially in the ESL/EFL contexts. Through a rigorous review of previous research on fostering thinking skills and provides a series of strategies or techniques, namely ContentBased Instruction, Task-Based Language Teaching Approach, English Literature, and Mental Modelling in Reading Comprehension, the authors argue that these strategies or techniques can be used for teaching or embedding thinking skills in the context of English as a Second/Foreign Language for young learners at primary school.
\end{abstract}

\section{Introduction}

The application of thinking skills, such as analysis, evaluation and interpretation results in clear and coherent communication (Kennedy, Fisher, \& Ennis, 1991). Thinking skills development is reported as an essential need for ESL and EFL settings (A. Chamot, 1995) and conducive to language learning and should be visible in language curriculum objectives. Developing thinking skills significantly develops language learners' speaking and listening exams scores (Y.T.C. Yang, Chuang, Li, \& Tseng, 2013), writing and speaking skills (Sanavi \& Tarighat, 2014; Shahini \& Riazi, 2011), vocabulary learning (Allahverdi \& Gholami, 2014), and reading comprehension performance (Fahim, Barjesteh, \& Vaseghi, 2012). 
However, in order to develop learners' thinking skills one cannot neglect the important element of age. According to Phillips (1993) exposing a young learner to a task beyond their cognitive level is as unreasonable as exposing a comparatively more developed learner to less challenging tasks. While the first scenario leads to learners' anxiety, distraction and low-motivation, the second one causes boredom and distraction. Cameron (2001) states that young language learners compared with adult learners are more enthusiastic, lively, and willing to please the teacher. In contrast, short-lived interest and motivation is more vivid in younger learners than what is seen in adult learners. Therefore, the awareness of teaching methods and techniques that positively contribute to learning in younger language learners is very important and necessary for English as a second or foreign language (ESL/EFL) teachers.

However, there is little review on strategies, techniques and methods suggested in the literature that can help ESL/EFL teachers at primary school to implement thinking skills in ESL/EFL classrooms. This paper intends to provide a brief review of previous research on techniques, approaches and methods proposed in the literature for developing thinking skills for young ESL/EFL language learners. Also, because the concept "young" might not introduce the exact age of learners, the authors chose studies addressing primary school children to introduce a referable age range for the readers. For the purpose of this article, the authors choose to focus on several strategies or techniques that have been studied by other researchers and used by primary school ESL/EFL teachers and their importance in promoting thinking skills in ESL/EFL learning, such as Content-Based Instruction, Task-Based Teaching Approach, English Literature and Mental Modelling in Reading Comprehension.]

\section{Content-Based Instruction (CBI) to Foster ESL Thinking Skills}

$\mathrm{CBI}$ is a concept of education that has strong connections to project work, task-based learning and a holistic approach to language instruction. The focus of a CBI lesson is on the topic or subject matter, in which during the lesson students are focused on learning about this particular subject matter. They learn about this subject using the language they are trying to learn, rather than their native language, as a tool for developing knowledge and so they develop their linguistic ability in the target language. This is thought to be a more natural way of developing language ability and one that corresponds more to the way we originally learn our first language (Brinton, Snow, \& Wesche, 2003). In the context of teaching and learning English as a second or foreign language (ESL/EFL) content-based instruction can be employed using the English language as the medium of communication in class for the purpose of teaching school subjects across all educational levels including primary school level. According to previous research, this approach contributes to communicative skills (Wesche \& Skehan, 2002), increased productivity along with improved listening skills (Chou \& Chou, 2015), and effective content learning (Mehisto, Marsh, \& Frigols, 2008). CBI approach, when effectively put into practice, is highly likely to engage learners in constant cognitive processes in an EFL/ESL environment, where the educational goal is not limited to learning the linguistic content.

With the $\mathrm{CBI}$ approach, language learners are exposed to authentic reading texts. Authentic content, highly beneficial for developing thinking skill, calls for language functions such as, 
INTERNATIONAL JOURNAL OF ACADEMIC RESEARCH IN PROGRESSIVE EDUCATION AND DEVELOPMENT

Vol. 7, No. 4, 2018, E-ISSN: 2226-6348 @ 2018 HRMARS

"comparing, describing, classifying, proving, debating, persuading, and evaluating" (A. U. Chamot \& O'Malley, 1994, p. 41) which develop thinking skills. In addition, due to the main purpose of reading or listening to an authentic input in classroom, which is understanding the content rather than developing language proficiency, thinking skills such as, interpretation, evaluation and synthesis are stimulated to enable the learner to interpret the unfamiliar content words. Therefore, the integration of language learning as a tool and learning a subject as a goal inherently develops thinking skills.

According to the concept of similarity-based induction, there is a tendency to project an attribute that is true for one entity to a very similar category (Brinton, Snow, \& Wesche, 2003). Therefore, any similarity that is spotted by the learner between novel linguistic input and their prior linguistic knowledge enables the learner to create a mental description and explanation of the unfamiliar second language (L2) input through reasoning (Brinton, Snow, \& Wesche, 2003). Drawing upon similarity-based induction, therefore, one can argue the novel input should be comprehensible enough to allow for drawing similarities between the novel input and learners' schema. This in turn will allow for the application of reasoning as a thinking skill. Therefore, CBI approach provides a beneficial path for language teachers to develop thinking skills in EFL/ESL as a teaching context whose pedagogies have not provided an explicit pedagogy to integrate thinking skills and teaching English as a second/foreign language.

Moreover, in CBI approach, the learner's main goal is to focus on the lesson content through the medium of the second language. To that end, learners rely on thinking skills to resolve linguistic obstacles that hinder understanding the content as this approach "requires students to synthesize facts and ideas from multiple sources" (Stoller, 1997). For example, the exposure to a novel and unfamiliar language structure or lexis leads the learner to compare their lexical or structural schema with the novel language input. This in turn will induce the need for confirmation of their speculated meaning. To confirm the accuracy of their speculation, the learner analyzes the linguistic context, interact with other peers and make further comparisons, or evaluate the outcome of their deduced meaning by analyzing further details. According to Gunning and Oxford (2014);

$\mathrm{CB}$ I approach to teaching L2 provides ample room for developing the habit of thinking due to the constant learners' challenge to decipher the content through using the target language. This involves learners in spontaneous creation of meaning of the unfamiliar content rather than the prompted attention to linguistic forms established by the teacher. The struggle to understand meaning is an optimal shift from focus on structure and lexis to focus on the content, which entails students' cognitive engagement. In addition, learners' efforts to make sense of the input, promotes language learning strategies that positively contribute to all thinking skills. (Gunning \& Oxford, 2014, pp. 6).

Previous studies maintain that despite no defined goal to develop thinking skills, CBI significantly develop thinking skill. For instance, Huang (2011) explored the motivated behaviour of young learners of English including attention and cognitive engagement in a content-based instruction course, by which various decisions and steps are adopted and practiced by teachers that 


\section{INTERNATIONAL JOURNAL OF ACADEMIC RESEARCH IN PROGRESSIVE EDUCATION AND}

DEVELOPMENT

Vol. 7, No. 4, 2018, E-ISSN: 2226-6348 ๑ 2018 HRMARS

contribute to thinking skills. Huang reported that the most highlighted teaching behaviors were providing room for students' interest to complete a task in limited time, providing the chance to express their views without being concerned about giving the right answer, arising their curiosity through postponing the teachers' comments on learners' answers, asking open-ended questions. The findings of the study imply that teachers need to adopt a meaning-focused approach to teaching so that the young language learners find the chance to negotiate meaning and enter a dialogical verbal communication.

There are four prototypes of $\mathrm{CBI}$, namely immersion education, sheltered courses, adjust courses and theme-based models (Duenas, 2004). However, the authors believe that the theme-based model the most appropriate model to contribute to thinking skills development at primary school second language classes. Theme-based teaching emphasizes the exposure of language learners to contextualized learning situations where different subjects are used as the content of language learning (Wesche \& Skehan, 2002). In this model, pre-selected themes are used to inform and direct a whole course of language learning where the integration of learning and teaching activities is determined by their content (Brinton, Snow, \& Wesche, 2003). In addition, as topics or themes are the "connecting thread" of language content (Cameron, 2001, p. 180) the "fragmentation and unconnected skill exercises" (Berry \& Mindes, 1993, p. 6) does not occur which contributes to meaningful content.

In order to teach English as a second or foreign language along with developing thinking skills, teachers need to create an anxiety-free learning experience for learners. This is because learning English is likely to cause anxiety among students (Yim, 2014), which can hinder the application of cognitive procedures in learning such as language learning strategies used in reading and listening tasks. This is because little or no anxiety in learning, consequently opens the door for thinking skills in EFL/ESL context. The theme-based model of teaching English views learning experience consonant with children's natural learning style (Cameron, 2001), hence, it is a suitable model to contribute to an anxiety-free learning experience. A theme-based model thus should entail the development of thinking skills as Freeman and Freeman (Freeman \& Freeman, 2006, p. 64) maintain that when a lesson content "is relevant and interesting, students are more likely to try harder to understand and to stay focused."

The link between thinking skills and the theme-based approach to teaching a second language can also be explained due to problem solving tasks inherent in theme-based approach. Stimulating the cognitive processes, problem solving is introduced as the main pillar of thinking skills in the literature of thinking skills in EFL/ESL contexts (Sokol, Oget, Sonntag, \& Khomenko, 2008; Waters, 2006). EFL/ESL students have to build a grammar model (Sokol et al., 2008), discover the implicit message in texts (Thakur \& Al-mahrooqi, 2015), evaluate different sources of information (Holliday \& Fagerheim, 2006), and compare and evaluate different viewpoints in listening practice (Ya Ting C Yang \& Gamble, 2013). In this regard, the theoretical foundations of theme-based model implicitly refer to the necessity of problem solving in achieving long lasting learning results in primary school language learners, through providing cognitively demanding task (Met, 1991), problem solving and synthesizing information (Grabe \& Stoller, 1997). 

DEVELOPMENT

Vol. 7, No. 4, 2018, E-ISSN: $2226-6348$ @ 2018 HRMARS

\section{Task-Based Language Teaching Approach}

Task-based language teaching (TBLT), also known as task-based instruction (TBI), focuses on the use of authentic language and on asking students to do meaningful tasks using the target language (Ellis, 2003). Defined by Ellis (2003), a task is a plan of work whose primary focus is meaning. Task fulfillment entails learner's cognitive engagement that hinges upon thinking skills such as analysis, synthesis, comparison and evaluation. Ellis (2005) refers to thinking skills in taskbased teaching in highlighting the cognitive processes required for task fulfillment. Ellis (2005, p. 3) mentions that doing a task engages learners "in decoding and encoding messages in the context of actual acts of communication" and in creating "pragmatic meaning", both of which depend upon memory, analysis, and synthesis in order to create meaning. In addition, a task should involve the learner in the cognitive process to reach the communicative goal. Communicative tasks usually involve two learners distinctly different from teacher-student interactions in terms of time pressure. The immediate need for responding to the interlocutor's questions results in an eagerness to find a way to construct meaning and verbalize it, for which the learner has to engage in thinking skills. In addition, constructing a solution in interactive tasks is cooperative where learners "satisfy their interlocutors' needs in addition to monitoring their own performance" (Pinter, 2007, p. 190).

Previous research illustrates how adopting tasks in teaching English to young learners leads to developed thinking skills. In one study, Pinter (2007) explored the effect of a common task called "spot the difference" on primary school students' thinking skills. The two participating primary school students were exposed to two pictures of the same house with three floors and were required to spot their differences through interacting with each other. The participants used analysis and interpretation throughout the task in order to resolve ambiguities about the pictures. For example, one of the participants' lack of knowledge of "kitchen" in English led to his peer's analysis and interpretation of his peer's need for knowing the equivalent term for "kitchen." The results revealed that despite participants' low English competence, the rate of oral interaction developed through stimulating thinking skills. This is where the thinking skills are stimulated in spot-the-difference tasks as learners constantly need to listen to their interlocutors while observing the picture, evaluate the peers' description and the available image, and consciously find the differences through on-the-spot interpretation.

Another method to use task-based teaching with an eye on thinking skills development is to merge extensive reading and task-based teaching (Green, 2005). The teacher first needs to know the most appealing book genres or titles by surveying students' interest. It should be noted that letting learners select their own preferred reading topics contributes to motivation and selfconfidence (Arnold, 2009). Then through a cycle of tasks students are exposed to task-based activities based on the topics of their interest, which is highly likely to contribute to critical thinking skills, and synthesis of information.

Developing thinking skills is also viable by providing planning time for children prior to task completion. In one study, Philp, Oliver, and Mackey, (2006) examined relationship between 21 children's planning and production. The participants were allowed time to get engaged in strategic pre-planning prior to carrying out the tasks while the researcher was monitoring the 


\section{INTERNATIONAL JOURNAL OF ACADEMIC RESEARCH IN PROGRESSIVE EDUCATION AND}

DEVELOPMENT

Vol. 7, No. 4, 2018, E-ISSN: 2226-6348 @ 2018 HRMARS

time. According to the results, providing planning time in task-based teaching results in more task negotiations, which requires thinking skills of analysis, comparison and interpretation of the interlocutors' discourse. The research findings revealed that the participating children provided more complex patterns in their oral production, which provides the evidence for the participants' engagement in thinking process according to the information processing theory.

Pogrow (1990) states that information processing theory is linked between problem-solving efforts and the corresponding cognitive processes. The time spent on planning a task leads to cognitive processes that contribute to problem-solving activities. If the oral task is a problem for a student, then providing time results in learners' engagement in the completion of the task. Therefore, the high rate of structural complexity found in participating learners (Philp et al., 2006) is the evidence for successful engagement in thinking skills as a result of providing sufficient time for a task.

In addition, the teacher can apply task-repetition. Repeating a task allows the learner to understand the conveyed implicit and explicit meaning finding more time to look into the structure of the input (Bygate, 2001). Guirao, de Larios and Coyle (2015), realized that children focus on language form after resolving the meaning issues in their first writing attempt. This finding is resonant with earlier findings that state meaning has a higher priority over the form (Van Patten, 1990). Once the meaning is resolved for the learners in the initial task fulfilment, the attention is freed to observe and screen new or challenging forms, for which the thinking skills such as monitoring, evaluation, selection and interpretation are used.

\section{English Literature}

Literature stimulates learners' thinking skills such as interpretation of the context and inferring meaning through contextual clues (Bland \& Lütge, 2013; Peham, 2009). The human's inherent need for narratives (Hardy, 1978) highlights the application of literature in first and second language learning especially at a younger age (Ghosn, 2002). Contrary to bottom-up approaches to language learning in which "pre-Chomskyan structuralists" (Hulstijn et al., 2014, p. 376) prioritized text decoding and linear understanding, literature provides an active role for children in the learning process. Ghosn (2002) suggests that the authentic content in English literature for EFL learners at primary school not only promotes their thinking skills but also positively contributes to young learners' interest in learning English.

The development of thinking skills is adversely affected by schooling (Greenfield, 2005), teacher beliefs' (A. Zohar, Degani, \& Vaaknin, 2001), and dearth of adequate pedagogies (Zohar, 2004). This inadequacy is also evident in EFL/ESL contexts, where English is entirely viewed as an academic discipline (Kang, 2000). However, literature serves to fill the gap in today's educational system regarding developing thinking skills due to motivational benefits for learners (Arnold, 2009), further exposure to language in a social setting (Green, 2005), and development of thinking skills through developed academic literacy (Ghosn, 2002). The literature provides manifold suggestions to use literature that engage learners in thinking skills. 


\section{INTERNATIONAL JOURNAL OF ACADEMIC RESEARCH IN PROGRESSIVE EDUCATION AND}

DEVELOPMENT

Vol. 7, No. 4, 2018, E-ISSN: 2226-6348 @ 2018 HRMARS

Listening to or reading literary works, such as a short stories, entails young learners' identification with the characters. Prior to learners' exposure to the story, the teacher may raise purposeful questions about learners' similar experiences, which subsequently leads to learners' evaluating their experiences with that of the story's characters. Moreover, learners' personal involvement in the story prepares them for subsequent teachers' questions about the story that tap into learners' interpretation, and synthesis of explanations. Table 2 represents the major techniques used in teaching literature in class along with the thinking skills that each one employs (Gomez, 2010; Kalantari \& Hashemian, 2015).

\begin{tabular}{|l|l|}
\hline Techniques/activity & Employed thinking skills \\
\hline $\begin{array}{l}\text { Drawing a scene on the whiteboard and } \\
\text { asking students identify the relevant part of } \\
\text { the story. }\end{array}$ & Memory, evaluation, analysis, interpretation. \\
\hline $\begin{array}{l}\text { Reading a part of a story and asking learners } \\
\text { to predict the subsequent section. }\end{array}$ & Analysis, interpretation, memory, synthesis. \\
\hline $\begin{array}{l}\text { Asking learners to write questions in groups } \\
\text { and exchange with other groups. }\end{array}$ & Evaluation, memory, analysis, application. \\
\hline $\begin{array}{l}\text { Reading the story aloud with students having } \\
\text { no access to its text. }\end{array}$ & Interpretation, analysis, evaluation, memory. \\
\hline $\begin{array}{l}\text { Comparing characters, finding similarities and } \\
\text { differences. }\end{array}$ & Evaluation, analysis, memory, interpretation. \\
\hline $\begin{array}{l}\text { Deducing the meaning of unknown words in } \\
\text { group completions. }\end{array}$ & $\begin{array}{l}\text { Interpretation, } \\
\text { evaluation, synthesis. }\end{array}$ \\
\hline $\begin{array}{l}\text { Evaluation of characters' decisions, reactions } \\
\text { and behaviors. }\end{array}$ & $\begin{array}{l}\text { Memory, evaluation, analysis, interpretation, } \\
\text { synthesis. }\end{array}$ \\
\hline \begin{tabular}{l} 
Choosing stories that are culturally familiar. \\
\hline
\end{tabular} & \begin{tabular}{l} 
Memory, evaluation, analysis. \\
\hline
\end{tabular}
\end{tabular}

Table 2 Techniques/Strategies in Teaching Literature to Improve Thinking Skills

In addition, the literature highlights the role of extensive reading as an efficient technique for exposing primary school students to literary works. Extensive reading for primary school EFL programs has yielded promising results in terms of developing thinking skills. In one study (Juan \& Cheng, 2008), the researchers sought to improve underachieving students' English scores through exposure to an extensive reading program. The results of the study illustrated that through exposing underachieving primary school EFL learners, students' attitudes to language learning in terms of engagement, confidence, interest, and satisfaction significantly increased. This finding corroborates the ideas of Oxford (1990) who suggested that the instruction of learning strategies generally contributes to EFL learners' attitude. In addition, Juan and Cheng 's (2008) research findings in terms of learners' developed engagement and motivation to learning accords with earlier (Reed \& Stavreva, 2006) and subsequent research findings (Ya Ting C Yang \& Gamble, 2013), which showed that thinking skills intervention increase learners' engagement, motivation and interest in the topic. 


\section{INTERNATIONAL JOURNAL OF ACADEMIC RESEARCH IN PROGRESSIVE EDUCATION AND}

DEVELOPMENT

Vol. 7, No. 4, 2018, E-ISSN: 2226-6348 @ 2018 HRMARS

In another study, Dato, Baharuddin, Rafik-galea, and Yuit (2015) investigated the effects of extensive reading cycles on oral communicative competence through extensive reading cycles or ERC, in which the fundamental concept supporting reading cycles is backed by Vygotskian outlook on learning highlighting interaction among learners to improve learning and thinking skills. The participants in the experimental group were exposed to an extensive reading program, for which they were asked to do their portion of extensive reading outside class to be able to participate in class discussions. The results proved that the program outcome was positive in that the participants in the experimental group became more active learners with developed thinking and reasoning, skills. They were also able to argue firmly, provide suggestions and negotiate meaning.

In his book titled "Teaching Children to Think", Fisher (1995) outlines different categories of thinking, which are in fact a simplified version of thinking skills introduced by Benjamin Bloom (1956). Table 3 illustrates different categories of thinking as introduced by Fisher (1995).

\begin{tabular}{|l|l|}
\hline Thinking Skill & Thinking Process Cues \\
\hline Knowledge & $\begin{array}{l}\text { Saying what you know, remember, describe, } \\
\text { repeat, define, identify, tell who, when, } \\
\text { which, where, what }\end{array}$ \\
\hline Comprehension & $\begin{array}{l}\text { Describe in your own words, tell how you feel } \\
\text { about, say what it means, explain, compare, } \\
\text { relate }\end{array}$ \\
\hline Analysis & $\begin{array}{l}\text { How you can use it, where does it lead you, } \\
\text { apply what you know, use it to solve } \\
\text { problems, demonstrate }\end{array}$ \\
\hline Synthesis & $\begin{array}{l}\text { What are the parts, the order, the reasons } \\
\text { why, the causes, the problems, the solutions, } \\
\text { the consequences }\end{array}$ \\
\hline Evaluation & $\begin{array}{l}\text { How might it be different, how else, what if, } \\
\text { suppose, develop, improve, create in your } \\
\text { own way }\end{array}$ \\
\hline
\end{tabular}

Table 3 Fisher 's Proposed Categories of Thinking Skills, Adopted from YÜCEL, (2008)

Adopting these categories, one is able to plan and prepare various activities for young language learners in the context of extensive reading. For example, Fisher (1995, p. 70) based on a story called "Goldilocks and the Three Bears" introduces cognitive questions to be used in storytelling in order to stimulate thinking skills through extensive reading. Table 4 illustrates these questions. 
INTERNATIONAL JOURNAL OF ACADEMIC RESEARCH IN PROGRESSIVE EDUCATION AND DEVELOPMENT

Vol. 7, No. 4, 2018, E-ISSN: 2226-6348 @ 2018 HRMARS

\begin{tabular}{|l|l|}
\hline Thinking Skill & Corresponding Question(s) \\
\hline Knowledge & $\begin{array}{l}\text { What happened in the story? } \\
\text { What did Goldilocks do in the Bear's home? }\end{array}$ \\
\hline Comprehension & $\begin{array}{l}\text { Why did it happen in that way? } \\
\text { Why did Goldilocks like little Bear's best? }\end{array}$ \\
\hline Application & $\begin{array}{l}\text { What would you have done? } \\
\text { What would have happened if Goldilocks had } \\
\text { come to your house? }\end{array}$ \\
\hline Analysis & $\begin{array}{l}\text { Which part did you like best? } \\
\text { Which parts could not be true? }\end{array}$ \\
\hline Synthesis & $\begin{array}{l}\text { Can you think of a different ending? } \\
\text { What would you have done if you were } \\
\text { Goldilocks? }\end{array}$ \\
\hline Evaluation & $\begin{array}{l}\text { What did you think of the story? } \\
\text { Was Goldilocks good or bad? Why? }\end{array}$ \\
\hline
\end{tabular}

Table 4 Questions used in Storytelling based on "Goldilocks and the Three Bears" Adopted from Fisher (1995)

By exposing language learners to storytelling tasks, the teacher devises various tasks that entail learners' engagement in thinking skills. It is believed that storytelling naturally engages young learners in learning and thereby arouses and maintains their interest (Alvarenga, 2012). Either in the first or second language, as soon as the teacher articulates the popular formula "once upon a time..." children begin using thinking skills such as prediction of they expect to hear. Problem solving, another form of thinking skill, has been shown to be applied by young learners as a result of using storytelling technique (As cited in Alvarenga, 2012).

In addition to teachers' questions, the literature offers other techniques to develop thinking skills through tasks. McGarrell (2004), in the book "Tell It Again! The New Storytelling Handbook for Primary Teachers" suggests cognitive strategies in the context of storytelling for children at primary school level that lead to their engagement in thinking skills. Table 5 illustrates the cognitive strategies, skills focus and strategies that teachers can use to develop thinking skills among learners at primary school. 
INTERNATIONAL JOURNAL OF ACADEMIC RESEARCH IN PROGRESSIVE EDUCATION AND DEVELOPMENT

Vol. 7, No. 4, 2018, E-ISSN: 2226-6348 @ 2018 HRMARS

\begin{tabular}{|c|c|c|}
\hline Activity & Strategy & Skill focus \\
\hline $\begin{array}{l}\text { Listening to a story } \\
\text { and participating }\end{array}$ & Making use of prior knowledge Predicting & Listening Speaking \\
\hline $\begin{array}{l}\text { Listening and } \\
\text { sequencing }\end{array}$ & $\begin{array}{l}\text { Using rhyming words as clues to meaning } \\
\text { Sequencing } \\
\text { Listening }\end{array}$ & Listening \\
\hline Picture diction & $\begin{array}{l}\text { Listening for specific information } \\
\text { Transferring spoken information into pictorial } \\
\text { form to show understanding }\end{array}$ & Listening and drawing \\
\hline Bingo & $\begin{array}{l}\text { Matching words to words or pictures to } \\
\text { pictures }\end{array}$ & $\begin{array}{l}\text { Using rhyming words } \\
\text { as clues to meaning } \\
\text { Sequencing } \\
\text { Listening }\end{array}$ \\
\hline $\begin{array}{l}\text { Sorting } \\
\text { Action }\end{array}$ & Classifying words into meaningful groups & $\begin{array}{l}\text { Developing } \\
\text { vocabulary }\end{array}$ \\
\hline $\begin{array}{l}\text { Action rhyme: Ten } \\
\text { Fat Sausages } \\
\text { Writing }\end{array}$ & $\begin{array}{l}\text { Practicing pronunciation Consolidating } \\
\text { vocabulary Using movement to aid memory }\end{array}$ & Chanting \\
\hline $\begin{array}{l}\text { Writing a shopping } \\
\text { list Matching }\end{array}$ & Memorizing Developing personalized lists & $\begin{array}{l}\text { Writing } \\
\text { developing } \\
\text { vocabulary }\end{array}$ \\
\hline $\begin{array}{l}\text { Matching captions to } \\
\text { pictures }\end{array}$ & $\begin{array}{l}\text { Observing } \\
\text { Using visual clues as aids to meaning Matching }\end{array}$ & Reading Writin0067 \\
\hline $\begin{array}{l}\text { Writing a menu } \\
\text { Conducting }\end{array}$ & $\begin{array}{l}\text { Memorizing Drafting and checking } \\
\text { Being creative and personalizing work }\end{array}$ & $\begin{array}{l}\text { Writing Developing } \\
\text { vocabulary Reading }\end{array}$ \\
\hline Conducting a survey & $\begin{array}{l}\text { Listening for specific information } \\
\text { Recording information on a chart } \\
\text { Working independently from teacher } \\
\text { Collaborating with classmates }\end{array}$ & Speaking Listening \\
\hline Making a box & $\begin{array}{l}\text { Observing } \\
\text { Listening for specific information and following } \\
\text { instructions Questioning/clarifying meaning }\end{array}$ & Listening Speaking \\
\hline Writing a word web & $\begin{array}{l}\text { Making meaningful associations Grouping } \\
\text { words together }\end{array}$ & $\begin{array}{l}\text { Writing } \\
\text { developing } \\
\text { vocabulary }\end{array}$ \\
\hline
\end{tabular}

Table 5; Story-based Activity Types and Related Cognitive Strategies, Adopted from McGarrell, (2004)

\section{Mental Modelling in Reading Comprehension}

The development of reading comprehension in learning ESL/EFL is mainly dependent on thinking skills, such as evaluation and making inferences (Fielding, Pearson, \& Pearson, 1994). Reading 


\section{INTERNATIONAL JOURNAL OF ACADEMIC RESEARCH IN PROGRESSIVE EDUCATION AND}

DEVELOPMENT

Vol. 7, No. 4, 2018, E-ISSN: 2226-6348 @ 2018 HRMARS

strategies enhance learners' textual comprehension through the application of thinking skills. Previous research on reading comprehension (Echeverri \& McNulty, 2010; Peña \& Cañón, 2008) illustrates the direct influence of learners' thinking skills on their ability to understand textual information. The precise engagement of thinking skills in reading comprehension can be traced in the suggested methods for the integration of thinking skills and reading comprehension.

Mental modelling is one of the effective techniques in reading comprehension (Duffy, Roehler, \& Herrmann, 1988). Modeling a superior reader in class, i.e., the teacher, the novice learner gets to know the teacher's mental processes through listening to the teacher's thinking aloud in his/her meaning negotiation. Mental modelling technique enables ESL/EFL novice learners to get an actual picture of cognitive processes such as reasoning that an advanced reader uses to comprehend a text. Modelling technique, which embraces the strategic (Chamot, 1993) and metacognitive (Schraw, 1994) characteristic of reading comprehension highlights different thinking skills for learners so that they are likely to adopt them in cognitive orientations towards reading comprehension seen in their teachers' ongoing reasoning while reading a text. Evaluation is also a thinking skill that learners mainly apply through mental modeling. The teacher's verbalized thinking allows the learner to notice the strategies that the teacher as an advanced reader applies. This, in turn, is highly likely to emulate the teachers' cognitive attempts by comparing their own thinking with that of their teacher.

The modelling technique is variation of raising young learners' metacognitive knowledge of reading strategies, which has positive contributions to young learners' reading comprehension. The educational research on children suggests that metacognition is a not only teachable but also necessary (Kelly, Moore, \& Tuck, 1994). Ferguson et al. (2011), in a longitudinal study found out that children's reading comprehension represented considerable improvement as the result of a metacognitive intervention practiced on 5-6-year-old learners. In addition, children at primary school can enhance their metacognitive skills through helping peers with reading comprehension questions. These findings substantiate the consensus among metacognition experts regarding the positive outcome of highlighting metacognition of reading comprehension through explicit instruction of reading strategies (National Reading Panel, 2000). All in all, the metacognitive approach to raising young learners' reading comprehension is inspired by the notion that learners' application of metacognitive and thinking skills in reading comprehension should be regulated within a social interaction with an accomplished reader.

\section{Conclusion}

The fostering of thinking skills to teaching English as a Second language is important in second language research. Developing thinking skills at primary school may be considered a challenging goal for three reasons: young language learners' age, abstract nature of thinking skills, the novelty of research discussion in this realm. However, there are various techniques, strategies and approaches that the literature suggests to improve teaching English young language. These strategies and techniques happen to stimulate thinking skills, such as analysis, synthesis, interpretation and evaluation. The integration of thinking skills and teaching English to young learners is an important effort in English as a second language education. Further research is essentially needed to explore the techniques and strategies regarding thinking skills in teaching 
INTERNATIONAL JOURNAL OF ACADEMIC RESEARCH IN PROGRESSIVE EDUCATION AND DEVELOPMENT

Vol. 7, No. 4, 2018, E-ISSN: 2226-6348 ๑ 2018 HRMARS

and learning of English as a second language. In addition, further research is needed to investigate second language teachers' and students' outlooks, beliefs and thinking skills techniques and strategies in teaching and learning of English as a second language.

\section{Corresponding Author}

Abu Bakar Razali (PhD), Department of Language and Humanities Studies, Faculty of Educational Studies, University Putra Malaysia, 43400 UPM Serdang, Selangor Darul Ehsan, Malaysia.

Email: abmr_bakar@upm.edu.my

\section{References}

Adams, J. W. (2013). A case study: Using lesson study to understand factors that affect teaching creative and critical thinking in the elementary classroom. Drexel University.

Allahverdi, S., \& Gholami, J. (2014). The Effects of Raising Iranian Intermediate EFL Learners ' Critical Thinking on Vocabulary Learning. Procedia - Social and Behavioral Sciences, 98, 212219.

Alvarenga, D. M. D. F. (2012). Developing Young Learners 'Logical / Deductive Thinking Skills and Second Language Skills through a CLIL approach. Universidade Nova de Lisboa.

Alwadai, M. A. (2014). Islamic Teachers' Perceptions of Improving Critical Thinking Skills in Saudi Arabian Elementary Schools. Journal of Education and Learning, 3(4), 37-48.

Anyachebelu, F. E. (2012). Teachers ' Extent of use of Teaching Strategies that Impact on the Thinking Skills of Learners. Journal of Educational and Social Research, 2(May), 409-415.

Arnold, N. (2009). Online extensive reading for advanced foreign language learners: An evaluation study, (7th ed.). Foreign Language Annals, 42(2), 340-366.

Berry, C. F., \& Mindes, G. (1993). Planning a theme-based curriculum: Goals, themes, activities, and planning guides for $4 s$ and 5s. Glenview, IL: Good Year Books.

Bland, J., \& Lütge, C. (eds). (2013). Children's Literature in Second Language Education. London: Bloomsbury Academic.

Bloom, B. S. (1956). Taxonomy of Educational Objectives: The Classification of Education Goals. Cognitive Domain. Handbook 1. London: Longman.

Bowman, L. A., Carpenter, J., \& Paone, R. A. (1998). Using graphic organizers, cooperative learning groups, and higher order thinking skills to improve reading comprehension. Saint Xavier University.

Brinton, D. M., Snow, M. A., \& Wesche, M. (2003). Content-based second language instruction. Ann Arbor: The University of Michigan Press. Brophy,

Bygate, M. (2001). Effects of task repetition on the structure and control of oral language. In et al. M. Bygate (Ed.), Researching pedagogic tasks: Second language learning teaching and testing (pp. 23-48). Harlow: Pearson Education.

Cameron, L. (2001). Teaching languages to young learners. Cambridge: Cambridge University Press.

Chamot, A. (1993). Student responses to learning strategy instruction in the foreign language classroom. Foreign Language Annals, 26(3), 308-331.

Chamot, A. (1995). Creating a community of thinkers in the ESL/EFL classroom. TESOL Matters, 5(5), 1-16. 
INTERNATIONAL JOURNAL OF ACADEMIC RESEARCH IN PROGRESSIVE EDUCATION AND DEVELOPMENT

Vol. 7, No. 4, 2018, E-ISSN: 2226-6348 @ 2018 HRMARS

Chamot, A. U., \& O'Malley, J. M. (1994). The CALLA handbook: Implementing the cognitive academic language learning approach. Reading: MA: Addison-Wesley.

Chou, M., \& Chou, M. (2015). A Content-Based Approach to Teaching and Testing Listening Skills to Grade 5 EFL Learners A Content-Based Approach to Teaching and Testing Listening Skills to Grade 5 EFL Learners, 4018(October).

Coyle, D., Hood, P., \& Marsh, D. (2010). Content and Language Integrated Learning. Cambridge: Cambridge University Press.

Dato, A., Baharuddin, H., Rafik-galea, S., \& Yuit, C. M. (2015). Evaluating the Effects of Extensive Reading Circles on Esl Learners ' Oral Communicative Competence Evaluating the Effects of Extensive Reading Circles on Esl, 4(1), 75-92.

Duenas, M. (2004). The Whats, Whys, Hows and Whos of Content-Based Instruction in Second/Foreign Language Education. International Journal of English Studies, 4(1), 73-96.

Duffy, G., Roehler, L., \& Herrmann, B. (1988). Modelling mental processes helps poor readers become strategic readers. The Reading Teacher, 41(8), 762-767.

Echeverri, L., \& McNulty, M. (2010). Reading Strategies to Develop Higher Thinking Skills for Reading Comprehension. PROFILE Issues in Teachers' Professional Development, 12(1), 107123.

Ellis, G., \& Brewster, J. (2014). Tell it Again! The Storytelling Handbook for Primary English Language Teachers. British Council.

Ellis, R. (2003). Task-based language learning and teaching. Oxford University Press. New York.

Ellis, R. (2005). Principles of Instructed Language Learning. System, 33.

Fahim, M., Barjesteh, H., \& Vaseghi, R. (2012). Effects of critical thinking strategy training on male/female EFL learners' reading comprehension. English Language Teaching, 5(1), 140145.

Ferguson, N., Currie, L.-A., Paul, M., \& Topping, K. (2011). The longitudinal impact of a comprehensive literacy intervention. Educational Research, 53(3), 237-256.

Fielding, L. G. L. G., Pearson, P. D., \& Pearson, D. P. (1994). Reading comprehnsion: What Works. Education Leadership, 51(5), 62-68.

Fisher, R. (1995). Teaching Children to Learn. Cheltenham. Stanley Thornes.

Freeman, D. E., \& Freeman, Y. S. (2006). Teaching language through content themes: Viewing our world as a global village. In T. A. Young \& N. L. Hadaway (Eds.), Supporting the literacy development of English learners: Increasing success in all classrooms (pp. 61-78). Newark, Del.: International Reading Association.

Gashan, A. K. (2015). Exploring Saudi Pre-service Teachers' Knowledge of Critical Thinking Skills and their Teaching Perceptions. International Journal of Education and Literacy Studies, 3(1).

Ghosn, I. K. (2002). Four good reasons to use literature in primary school ELT. ELT Journal, 56(2), 172-179.

Goh, C. ., \& Taib, Y. (2006). Metacognitive instruction in listening for young learners. ELT Journal, 60(3), 222-232.

Gomez, M. B. (2010). How to use tales for the teaching of vocabulary and grammar in a primary education English class. Resla, 23, 31-52.

Grabe, W., \& Stoller, F. L. (1997). Content-Based Instruction: Research Foundations. The ContentBased Classroom: Perspectives on Integrating Language and Content.

Green, C. (2005). Integrating extensive reading in the task-based curriculum. ELT Journal, 59(4), 
INTERNATIONAL JOURNAL OF ACADEMIC RESEARCH IN PROGRESSIVE EDUCATION AND

DEVELOPMENT

Vol. 7, No. 4, 2018, E-ISSN: 2226-6348 @ 2018 HRMARS

306-311.

Guirao, J. C., de Larios, J. R., \& Coyle, Y. (2015). The use of models as a written feedback technique with young EFL learners, 52.

Gunning, P., \& Oxford, R. L. (2014). Children's learning strategy use and the effects of strategy instruction on success in learning ESL in Canada. System, 43, 82-100.

Hardy, B. (1978). Narrative as the primary act of mind. In M. Meek, A. Warlow, \& G. Barton (Eds.), The Cool Web: The Pattern of Children's Reading. New York: Atheneum.

Higgins, S., Hall, E., Baumfield, V., \& Moseley, D. (2005). A meta-analysis of the impact of the implementation of thinking skills approaches on pupils. London: Univrsity of London, london.

Holliday, W., \& Fagerheim, B. (2006). Integrating information literacy with a sequenced English composition curriculum. Portal: Libraries and the Academy, 6(2), 169-184.

Hu, W., Adey, P., Jia, X., Liu, J., Zhang, L., Li, J., \& Dong, X. (2011). Effects of a "learn to think" intervention programme on primary school students. The British Journal of Educational Psychology, 81(Pt 4), 531-57.

Huang, K. M. (2011). Motivating lessons: A classroom-oriented investigation of the effects of content-based instruction on EFL young learners' motivated behaviours and classroom verbal interaction. System, 39(2), 186-201.

Hulstijn, J. H., Young, R. F., Ortega, L., Bigelow, M., DeKeyser, R., Ellis, N. C., ... Talmy, S. (2014). Bridging the Gap. Studies in Second Language Acquisition, 36(03), 361-421.

Juan, L., \& Cheng, C.-K. (2008). Using Extensive Reading to Improve the Learning Performance and Attitude of Elementary School Remedial Students. English Teaching \& Learning, 32(4), 41-83.

Kalantari, F., \& Hashemian, M. (2015). A Story-Telling Approach to Teaching English to Young EFL Iranian Learners. English Language Teaching, 9(1), 221.

Kang, D.-H. (2000). Motivation and Foreign Language Learning in Korean EFL Context. The Journal of English Language Teaching, 13(1), 1-23.

Kelly, M., Moore, D. . W., \& Tuck, B. . F. (1994). Reciprocal teaching in a regular primary school classroom. The Journal of Educational Research, 55(1), 53-61.

Kennedy, M., Fisher, M. B., \& Ennis, R. H. (1991). Critical thinking: literature review and needed research. In L. Idol \& B. F. Jones (Eds.), Educational values and cognitive instruction: Implications for reform (pp. 11-40). Hillsdale, NJ: Erlbaum.

McGarrell, H. (2004). Tell It Again! The New Storytelling Handbook for Primary Teachers. Modern English Teacher.

Mehisto, P., Marsh, D., \& Frigols, M. J. (2008). Uncovering CLIL: Content and Language Integrated Learning in Bilingual and Multilingual Education. Oxford: Macmillan education.

Met, M. (1991). Learning language through content: Learning content through language. Foreign Language Annals, 24(4), 281-295.

National Reading Panel. (2000). Teaching children to read: An evidence-based assessment of the scientific research literature on reading and its implications for reading instruction. NIH Publication No. 00-4769 (Vol. 7).

Oxford, R. (1990). Language learning strategies: What every teacher should know. Massachusetts: Heinle and Heinle Publishers.

Pang, Y. (2013). Graphic organizers and other visual strategies to improve young ELLs' reading 
INTERNATIONAL JOURNAL OF ACADEMIC RESEARCH IN PROGRESSIVE EDUCATION AND

DEVELOPMENT

Vol. 7, No. 4, 2018, E-ISSN: 2226-6348 @ 2018 HRMARS

comprehension. Nera, 48(2), 52-58.

Pani, S. (2004). Reading strategy instruction through mental modelling, 58(October), 355-362.

Park, J. Y. (2012). A different kind of reading instruction: Using visualizing to bridge reading comprehension and critical literacy. Journal of Adolescent and Adult Literacy.

Peham, G. (2009). Setting up an Extensive Reading Program in Austria: A Practical Guide. Doctoral dissertation, uniwien.

Peña, A. N., \& Cañón, J. M. (2008). Developing Cognitive Processes in Teenagers through the Reading of Short Stories. Profile Issues in Teachers' Professional Development, (9), 9-22.

Phillips, S. (1993). Young Learners. Oxford: Oxford University Press.

Philp, J., Oliver, R., \& Mackey, A. (2006). The impact of planning time on children 's task-based interactions. System, 34(4), 547-565.

Pilten, G. (2010). Evaluation of the skills of 5 th grade primary school students' high-order thinking levels in reading. Procedia - Social and Behavioral Sciences, 2(2), 1326-1331.

Pinter, A. (2007). Some benefits of peer-peer interaction: 10 -year-old children practising with a communication task. Language Teaching Research, 11(2), 189-207.

Pogrow, S. (1990). HOTS: Using computers to develop thinking skills in students at risk. New York: Scholastic, Inc. Pogrow,

Polat, S. (2015). Content analysis of the studies in Turkey on the ability of critical thinking. Kuram ve Uygulamada Egitim Bilimleri, 15(3), 659-670.

Reed, S. L., \& Stavreva, K. (2006). Layering knowledge: information literacy as critical thinking in the literature classroom. Pedagogy, 6(3), 435-452.

Rodrigues, S. M. F. M. (2006). Professional and pedagogical implications of training in thinking skills interventions: investigating primary school teachers' attitudes and beliefs about teaching thinking in England and in Portugal. Unpublished Ph. D. Dissertaion, School of Education,University of Newcastle, The UK.

Salmon, A. K. (2010). Engaging young children in thinking routines. Childhood Education, 86(3), 132-137.

Sanavi, R. V., \& Tarighat, S. (2014). Critical Thinking and Speaking Proficiency: A Mixed-method Study. Theory and Practice in Language Studies, 4(1), 79-87.

Sardare, S. A., \& Saad, M. R. M. (2013). Malaysian Primary School ESL Teachers' Questions during Assessment for Learning. English Language Teaching, 6(8), 1-9.

Schraw, G. (1994). The effect of metacognitive knowledge on local and global monitoring. Contemporary Educational Psychology, (19), 143-154.

Shahini, G., \& Riazi, A. M. (2011). A PBLT approach to teaching ESL speaking, writing, and thinking skills. ELT Journal, 65(2), 170-179.

Sokol, A., Oget, D., Sonntag, M., \& Khomenko, N. (2008). The development of inventive thinking skills in the upper secondary language classroom. Thinking Skills and Creativity, 3(1), 34-46.

Stoller, F. (1997). Project Work - A Means to Promote Langugage Content. English Teaching Forum Online, 35(4), 29-37.

Thakur, V. S., \& Al-mahrooqi, R. (2015). Orienting ESL / EFL Students towards Critical Thinking through Pictorial Inferences and Elucidation : A Fruitful Pedagogic Approach, 8(2), 126-133.

Van Patten, B. (1990). Attending to content and form in input: an experiment in con- sciousness. Studies in Second Language Acquisition, (12), 287-310.

Waters, A. (2006). Thinking and language learning. ELT Journal, 60(4), 319-327. 
INTERNATIONAL JOURNAL OF ACADEMIC RESEARCH IN PROGRESSIVE EDUCATION AND DEVELOPMENT

Vol. 7, No. 4, 2018, E-ISSN: 2226-6348 ๑ 2018 HRMARS

Wesche, M. B., \& Skehan, P. (2002). Communicative, task-based, and content-based language instruction. In R. B. Kaplan (Ed.), The Oxford Handbook of Applied Linguistics (pp. 207-228). Oxford, England: Oxford University Press.

Yang, Y. T. C., Chuang, Y. C., Li, L. Y., \& Tseng, S. S. (2013). A blended learning environment for individualized English listening and speaking integrating critical thinking. Computers and Education, 63, 285-305.

Yang, Y. T. C., \& Gamble, J. (2013). Effective and practical critical thinking-enhanced EFL instruction. ELT Journal, 67(4), 398-412.

Yim, S. Y. (2014). An anxiety model for EFL young learners: A path analysis. System, 42(1), 344354.

YÜCEL, M. (2008). Improving Thinking Skills of Young Learners Through Task-Based Llearning. ÇUKUROVA UNIVERSITY.

Zohar, A. (2004). Elements of Teachers ' Pedagogical Knowledge Regarding Instruction of Higher Order Thinking. Journal of Science Teacher Education, 15(4), 293-312.

Zohar, A., Degani, A., \& Vaaknin, E. (2001). Teachers ' beliefs about low-achieving students and higher order thinking. Teaching and Teacher Education, 17(4), 469-485. 